\title{
THE IMPACT OF DIFFERENT SOWING-TIMES OF THE QUINOA (CHENOPODIUM QUINOA WILLD.) AND ITS VARIETIES ON THE YIELD AND YIELD COMPONENTS IN TURKEY-MARDIN ECOLOGY CONDITION
}

\author{
AltunER, F. $^{1 *}-$ ORAL, E. ${ }^{2}-$ KULAZ, H. ${ }^{2}$ \\ ${ }^{1}$ Department of Plant and Animal Production, Gevaş Vocational School of Higher Education, \\ Yüzüncü Yıl University, Gevaş, Van, Turkey \\ ${ }^{2}$ Department of Field Crops, Faculty of Agriculture, Yüzüncü Yıl University, 65100, Van, \\ Turkey \\ *Corresponding author \\ e-mail:faltuner@gmail.com \\ (Received $11^{\text {th }}$ Apr 2019; accepted $19^{\text {th }}$ Jun 2019)
}

\begin{abstract}
This research was planned to determine the correct sowing times of quinoa (Chenopodium quinoa Willd.) varieties under the ecological conditions of Turkey-Mardin. The study was conducted in three different sowing times (15 March, 30 March and 15 April) using 2 quinoa varieties in aqueous conditions in 2017 spring period with three repetitions. At the end of the research; according to the data obtained, the number of plants in the harvest $\left(15.4-29.2\right.$ plants $\left./ \mathrm{m}^{2}\right)$, plant height $(73.9-90.3 \mathrm{~cm})$, the main panicle length $(31.1-43.9 \mathrm{~cm})$, the number of panicle branches $(23.7-29.7$ units plant), thousand weight (3.37-3.46 g), grain yield (125.6-1339 $\left.\mathrm{kg} \mathrm{ha}^{-1}\right)$, hectoliter weight (6220-6280 kg ha-1) and crude protein ratio $(14.8-15.7 \%)$ ranged. The highest grain yield was obtained from the application of Valiente and Titicaca (April 15) with 1345-1333 kg ha-1, respectively. As a result of these properties, it was concluded that the most suitable planting time for quinoa (Chenopodium quinoa Willd.) cultivation in Mardin may be the second week of April.
\end{abstract}

Keywords: quinoa, Mardin ecology, sowing date, grain yield, agronomy

\section{Introduction}

Parallel to the increasing population of the world in our day, the dependency to the natural resources and consumption has increased. Additionally, the global warming, which has increased in the same period, caused important problems about sufficient and balanced nutrition (Kaya and Karaer, 2017). This case encouraged human beings to find and develop new resources. Particularly the usage of types and varieties of plants, which will increase the yield and quality in animal and plant production and which will be produced under all climates and natural conditions, has been obligatory (K1r, 2016). It is a known fact that grains such as wheat, barley, and rice, which constitute the most basic food source in human nutrition, cause celiac disease (Özkaya, 1999; Battais et al., 2005). Therefore, quinoa (Chenopodium quinoa Willd.) can play an important role as an alternative plant, which can be cultivated in a large geography and which has the potential to remove this negativity for the nutrition. To define botanically, quinoa (Chenopodium quinoa Willd.) is a dicotyledonous annual plant from the Chenopodiaceae family. It has been cultivated in many countries such as Bolivia, Peru, Ecuador, and Chile since the ancient times and its homeland is known to be the South America (Pearsall, 1992). In recent years, the trend in the US and European countries have started to plant quinoa while newly recognized in 
Turkey. However, consumption in the world and Turkey is increasing rapidly. Quinoa is a region in the And mountain region on the west coast of South America, where its homeland is very cold and has high plateaus. It is mainly grown in Colombia, Argentina, Peru, Bolivia, Chile and Ecuador. According to data, 146.735 tons of yield is obtained from 173.242 hectares in the world (FAO, 2017). In our country there is no official data. The fact that this plant has a rich nutritional value caused a rapid increment in cultivation sites. Known little in our country, this plant attracted intensive attention particularly in America and Europe. In return to this attraction, the year 2013 was declared as the year of quinoa (Chenopodium quinoa Willd.) by the United Nations (Miranda et al., 2012).

Particularly today, when more than half of the world population is exposed to poor or irregular nutrition, there is a need for alternative products to solve this problem. Accepted as one of these plants, quinoa is named as "super food", "miracle grain", or "astronaut grain". The main reason to define it in these terms is the existence of protein and amino acid at high levels in the grains. Besides this content, the levels of A, B, C, D, E, and K vitamins are at high levels as well (FAO, 2017).

Quinoa cultivation should be generalized as an alternative product in our country and in regions with grain agriculture. It will make important contributions in adding a significant amount of marginal terrains, mined terrains being in the first place, to the production (Kir and Temel, 2017). For this purpose, successful results were obtained by the contracted farmers in the production of these seeds, which certain firms brought to Mardin province. Thus, an agricultural production with high added value will be introduced to the region. In this purpose, it is necessary to determine the most appropriate sowing time and accurate cultivation methods of the quinoa varieties and to encourage its cultivation.

In this study, it was aimed at determining the yield and yield components of quinoa (Chenopodium quinoa Willd.) varieties in different sowing times that are not being widely cultivated in our region but considered to increase in a short period.

\section{Materials and methods}

This study was conducted in a single year during the cropping season of the 2017 spring period in the ecological conditions of Mardin-Kiziltepe $\left(37^{\circ} 11^{\prime} 12^{\prime} \mathrm{N}\right.$ and 40³6'43'E) (Fig. 1). In the trial, South American-origin Valiente and Titicaca quinoa (Chenopodium quinoa Willd.) varieties were used, which were provided by certain companies.

The climate information concerning the research area is given in the Table 1 and the properties of the soil are given in Table 2. As is seen in Table 1, it was observed that the temperature and precipitation were lower while the relative humidity was high during the research in the production season of 2017. According to these results, the distribution and amount of the precipitation over the year caused differences between the yield and yield components based on the cultivation times.

As the conclusion of the analysis of the soil samples taken from the research area, it was observed that there was no problem about the salinity and alkalinity. Moreover, it was determined that the soil samples were mid-calcareous and weak in terms of organic matters. The results concerning the $\mathrm{pH}$, salt, lime, and organic matter analyses of the soil samples are given in Table 2. 


$$
-10107 \text { - }
$$

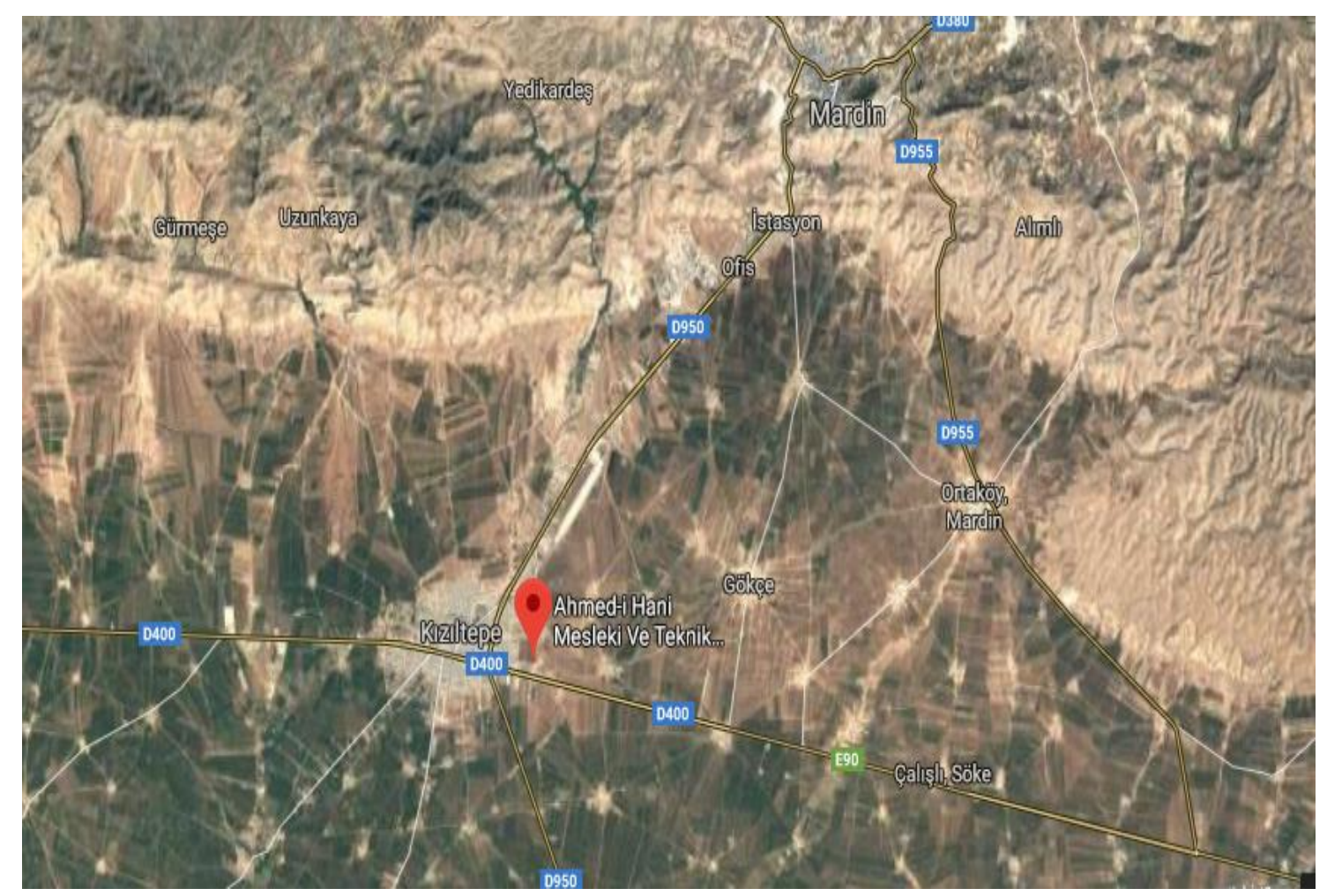

Figure 1. The research was conducted in Kiziltepe/Mardin of Turkey

Table 1. Climate data concerning the research period at Mardin Weather Regional Station, between February and July calculated from daily climate data, 2017 (Anonymous, 2017)

\begin{tabular}{c|c|c|c|c|c|c}
\hline \multirow{2}{*}{ Months } & \multicolumn{2}{|c|}{ Rel. humidity (\%) } & \multicolumn{2}{c|}{ Mean temp. $\left({ }^{\circ} \mathbf{C}\right)$} & \multicolumn{2}{c}{ Precipitation (mm) } \\
\cline { 2 - 7 } & $\mathbf{2 0 1 7}$ & ALY* & $\mathbf{2 0 1 7}$ & ALY* $^{*}$ & $\mathbf{2 0 1 7}$ & ALY* \\
\hline February & 51.3 & 51.0 & 3.8 & 3.9 & 23.2 & 64.4 \\
March & 62.5 & 62.9 & 9.7 & 9.0 & 101.7 & 99.6 \\
April & 55.7 & 55.2 & 13.5 & 15.2 & 109.2 & 98.5 \\
May & 44.0 & 43.8 & 19.7 & 19.6 & 60.3 & 57.0 \\
June & 26.1 & 25.8 & 26.8 & 26.0 & 0.2 & 2.2 \\
July & 17.0 & 16.5 & 32.4 & 32.1 & 0.0 & 0.6 \\
Total & & & & & 294.6 & 322.3 \\
\hline Average & $\mathbf{4 2 . 8}$ & $\mathbf{4 2 . 5}$ & $\mathbf{1 7 . 6}$ & $\mathbf{1 7 . 7}$ & & \\
\hline
\end{tabular}

ALY: average of the long years

Table 2. Soil analysis results about the trial area

\begin{tabular}{|c|c|c|c|c|c|c|c|}
\hline \multicolumn{3}{|c|}{$\begin{array}{c}\text { Soil texture (\%) } \\
\text { Sand alluvium clay }\end{array}$} & \multirow{2}{*}{$\begin{array}{c}\mathbf{p H} \\
7.2\end{array}$} & \multirow{2}{*}{$\begin{array}{c}\begin{array}{c}\text { Organic matter } \\
(\%)\end{array} \\
1.8\end{array}$} & \multirow{2}{*}{$\begin{array}{c}\begin{array}{c}\mathbf{P} \\
\text { (phosphor) } \\
\text { ppm }\end{array} \\
28\end{array}$} & \multirow{2}{*}{$\begin{array}{c}\begin{array}{c}\mathbf{K} \\
\text { (potassium) } \\
\mathbf{p p m}\end{array} \\
265\end{array}$} & \multirow{2}{*}{$\begin{array}{c}\begin{array}{c}\text { CaCO3 } \\
\text { (lime) }\end{array} \\
\% \\
18.95\end{array}$} \\
\hline 54.3 & 27.4 & 11.5 & & & & & \\
\hline
\end{tabular}

Mardin Artuklu University Central Laboratory 
This study randomized blocks were developed as 3-repeat according to the experimental design. The quinoa varieties (Valiente and Titicaca), which were obtained by a special company and used in the research, were applied to main parcels, and the sowing times (15 March, 30 March, and 15 April) were applied to the sub-parcels (Figs. 2 and 3). In the trial, each parcel (6 m-long and $2 \mathrm{~m}$-wide) was sewn at a 1.0$1.5 \mathrm{~cm}$ depth as 6 lines. The distances among the lines were $40 \mathrm{~cm}$. The tillage process was elaborately conducted to prevent clods in the soil and for an orderly germination and first emergence. Since the quinoa seeds are not sewn too deep, and in order for the germination and the first emergence not to be interrupted as a conclusion of the shallow sowing and the crusting soil, springer irrigation was applied after each sowing time. In order to guarantee the number of plants in a unit area, the sowings were applied denser, and once the plants reached a height of $10-15 \mathrm{~cm}$, the distances between the plants were kept at $8 \mathrm{~cm}$ through thinning. A distance of $2 \mathrm{~m}$ was left among the blocks and $0.5 \mathrm{~m}$ among the parcels. Before the sowing, $150 \mathrm{~kg} \mathrm{ha}^{-1}$ DAP (Diammonium Phosphate) was applied as the bottom fertilizer. After the thinning (while the plants were about 10$15 \mathrm{~cm}$ ) second nitrogenous manure (ammonium sulphate) was implemented with a calculation of $50 \mathrm{~kg} \mathrm{~N} \mathrm{ha}^{-1}$. One month after the sowing, hoeing was applied to clean the weeds. Hand and hoes were used mechanically in weeding. As the foils turned yellow, started to drop and as the flower clusters dried, the plants were harvested.

In each parcel, 10 plants were selected among the ones that became harvestable, and the following measurements were obtained respectively. Leaving the edge effect, the remaining parts of the parcels were sickled and they were blended after several days of drying. After the seeds matured in the plants were neglected as the edge effect of $50 \mathrm{~cm}$ from the parcel heads with 1 and 6 rows. The remaining $5 \times 1.2 \mathrm{~m}^{2}=6 \mathrm{~m}^{2}$ area was harvested and yield per decare was calculated. The observations in the research were determined as the number of plants in the harvest (plant number $\left.\mathrm{m}^{-2}\right)$, plant height $(\mathrm{cm})$, the main panicle length $(\mathrm{cm})$, the number of panicle branches (plant number ${ }^{-1}$ ), total yield $\left(\mathrm{kg} \mathrm{ha}^{-1}\right)$, grain yield $\left(\mathrm{kg} \mathrm{ha}^{-1}\right)$, harvest index $(\%)$, thousand weight $(\mathrm{g})$, hectoliter weight (kg) and crude protein ratio (\%) (K1r and Temel, 2017).

The data obtained from the research were analyzed through variance analysis by means of CoStat (version 6.303) program, and LSD $(0.05,0.01)$ multiple comparison test was implemented to determine the significance levels of the differences among the implementations.

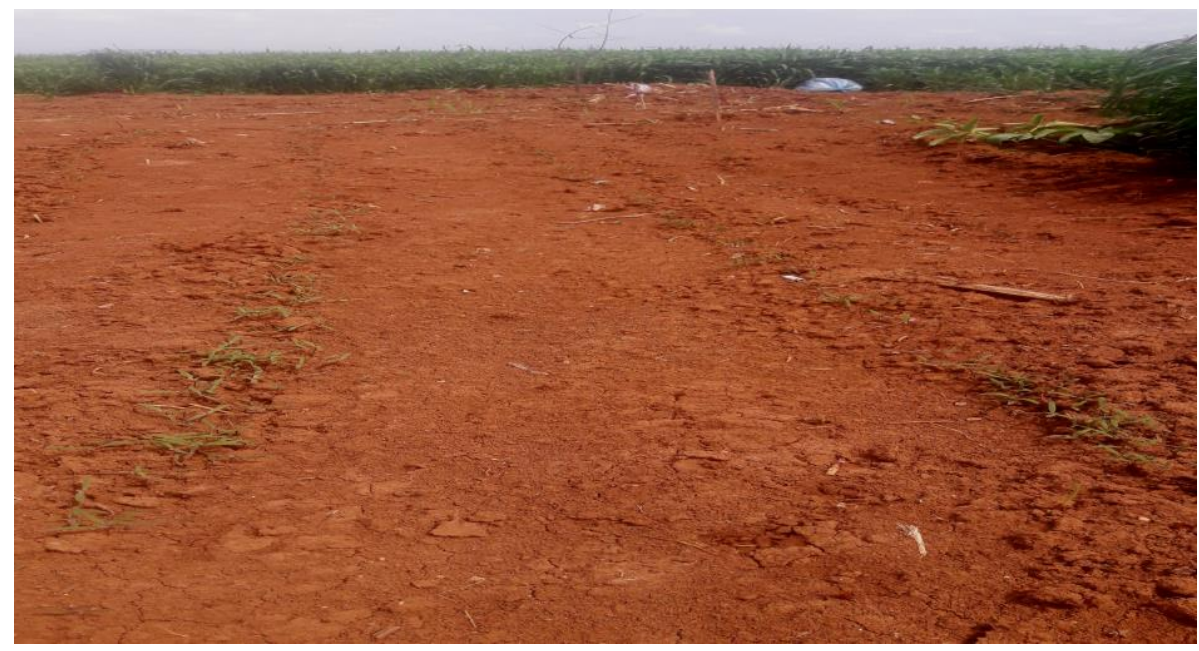

Figure 2. View of the area during the first sowing date 


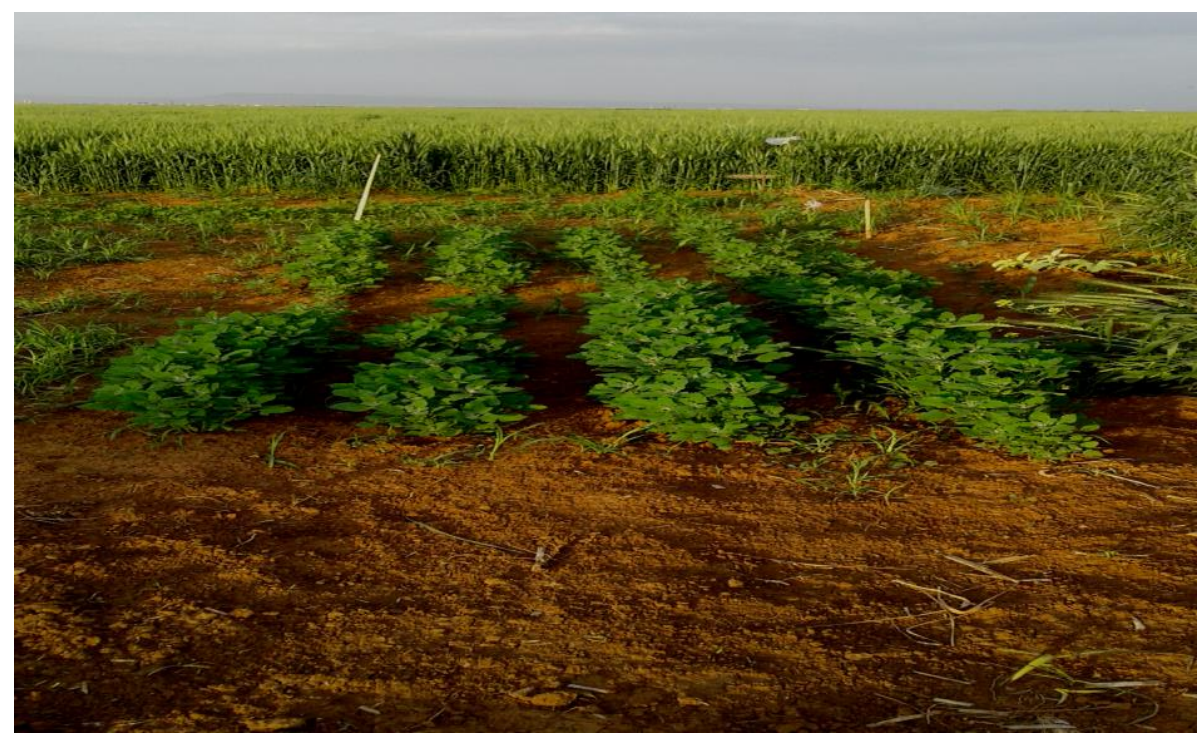

Figure 3. View of the area during the third sowing date

\section{Results}

The mean squares, which were obtained through the variance analysis concerning the mean values of number of plants in the harvest $(\mathrm{NPH})$, plant height $(\mathrm{PH})$, the main panicle length (MPL), the number of panicle branches (NPB), grain yield (GY), thousand weight (TW), hectoliter weight (HW) and crude protein ratio (CPR) that were obtained from trials of 2 quinoa (Chenopodium quinoa Willd.) varieties in different times, are given in Table 3 and the results of the comparisons of the mean values are given in Table 4.

Table 3. Mean squares (MS) obtained from the variance analysis results

\begin{tabular}{c|c|c|c|c|c|c|c|c|c}
\hline V.K. & DF & NPH & PH & MPL & NPB & TW & GY & HW & CPR \\
\hline V & 1 & $52.70 *$ & $875.10^{* *}$ & $112.50^{*}$ & $4.50 \mathrm{~ns}$ & $0.03 \mathrm{~ns}$ & $144.5 *$ & $0.09 \mathrm{~ns}$ & $0.02 \mathrm{~ns}$ \\
ST & 2 & $6.92 * *$ & $168.40 \mathrm{~ns}$ & $33.69 \mathrm{~ns}$ & $57.30 * *$ & $0.02 \mathrm{~ns}$ & $316.12 \mathrm{~ns}$ & $0.05 \mathrm{~ns}$ & $1.14 \mathrm{~ns}$ \\
V $\times$ ST & 2 & $10.58 \mathrm{~ns}$ & $0.35 \mathrm{~ns}$ & $46.33^{* *}$ & $21.30 \mathrm{~ns}$ & $0.02 \mathrm{~ns}$ & $283.13 * *$ & $1.72 * *$ & $0.46 \mathrm{~ns}$ \\
Error & 12 & 366.14 & 787.12 & 224.05 & 383.33 & 0.05 & 203.54 & 3.38 & 5.25 \\
Ctotal $_{\text {LSD }}$ & 17 & 436.6 & 1830.9 & 416.6 & 466.50 & 0.12 & 1671.1 & 5.24 & 6.87 \\
CV $(\%)$ & - & 6.30 & 9.24 & 4.83 & 6.45 & 0.15 & 10.05 & 0.61 & 0.75 \\
\hline
\end{tabular}

LSD: least significant effect, CV: coefficient of variation, d.f.: degree of freedom, ${ }^{*}$ value significant at 0.05 probability level, **value significant at 0.01 , ns: not significant. V: variety, ST: sowing time, NPH: number of plants in the harvest, PH: plant height, MPL: main panicle length, NPB: number of panicle branches, GY: Grain YIELD, TW: thousand weight, HW: hectoliter weight, and CPR: crude protein ratio

\section{Number of plants in the harvest (plants/ $\mathrm{m}^{2}$ ) and the plant height (cm)}

According to the results of the research, the variety and the sowing time (ST) values of the quinoa were determined to be statistically significant (Table 3). The number of plants in the harvest was detected higher in the Titicaca $\left(23.5\right.$ plants $\left./ \mathrm{m}^{2}\right)$ variety 


$$
-10110 \text { - }
$$

compared to the Valiente (20.1 plants $/ \mathrm{m}^{2}$ ) variety (Table 4). Based on the sowing times, it was determined that the highest NPH was 26.9 plants $/ \mathrm{m}^{2}$ during the $3 \mathrm{rd}$ sowing time (15 April), while the lowest NPH was 17.1 plants $/ \mathrm{m}^{2}$ in the 1 st sowing time (1 March) (Fig. 4).

Table 4. The impact of different sowing times on the number of plants in harvest and plant height of quinoa varieties

\begin{tabular}{|c|c|c|c|c|c|c|c|c|}
\hline \multicolumn{5}{|c|}{ Number of plants in the harvest (plants/m²) } & \multicolumn{4}{|c|}{ Plant height (cm) } \\
\hline \multicolumn{5}{|c|}{$\begin{array}{l}\text { Sowing times } \\
\end{array}$} & \multicolumn{4}{|c|}{ Sowing times } \\
\hline Variety & 1 & 2 & 3 & Mean & 1 & 2 & 3 & Mean \\
\hline Valiente & 15.4 & 20.1 & 24.7 & $20.1 \mathrm{~B}$ & 87.5 & 82.9 & 90.3 & $86.4 \mathrm{~A}$ \\
\hline Titicaca & 18.8 & 22.5 & 29.2 & $23.3 \mathrm{~A}$ & 76.1 & 68.8 & 73.9 & $72.9 \mathrm{~B}$ \\
\hline Mean & $17.1 \mathrm{C}$ & $21.3 \mathrm{~B}$ & $26.9 \mathrm{~A}$ & & 81.8 & 80.7 & 82.1 & \\
\hline
\end{tabular}

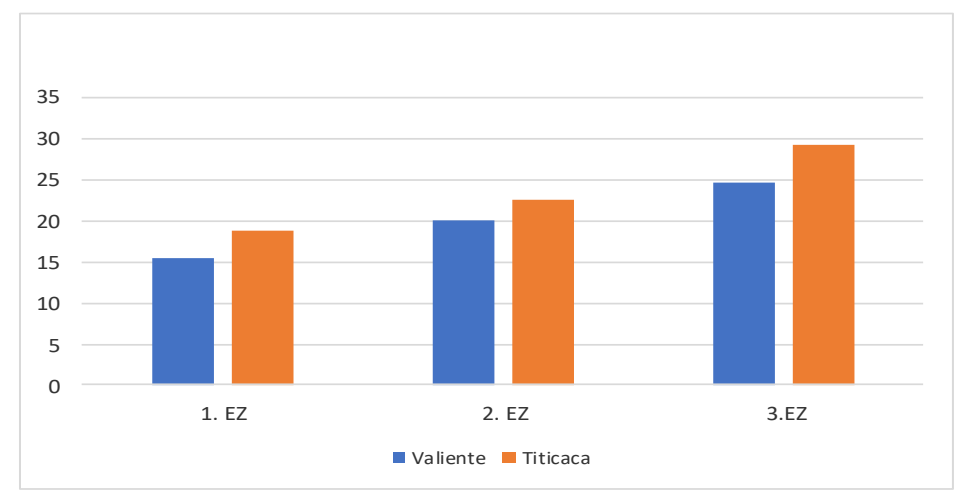

Figure 4. The impact of sowing times on the number of plants in the harvest in Quinoa. (EZ: sowing time)

The impact of different sowing times (ST) on the plant height in quinoa varieties was determined to be statistically significant $(\mathrm{p}<0.01)$ (Table 3). According to the results, the plant height was detected as $86.9 \mathrm{~cm}$ in the Valiente variety, while it was 72.9 in Titicaca variety (Table 4; Fig. 5).

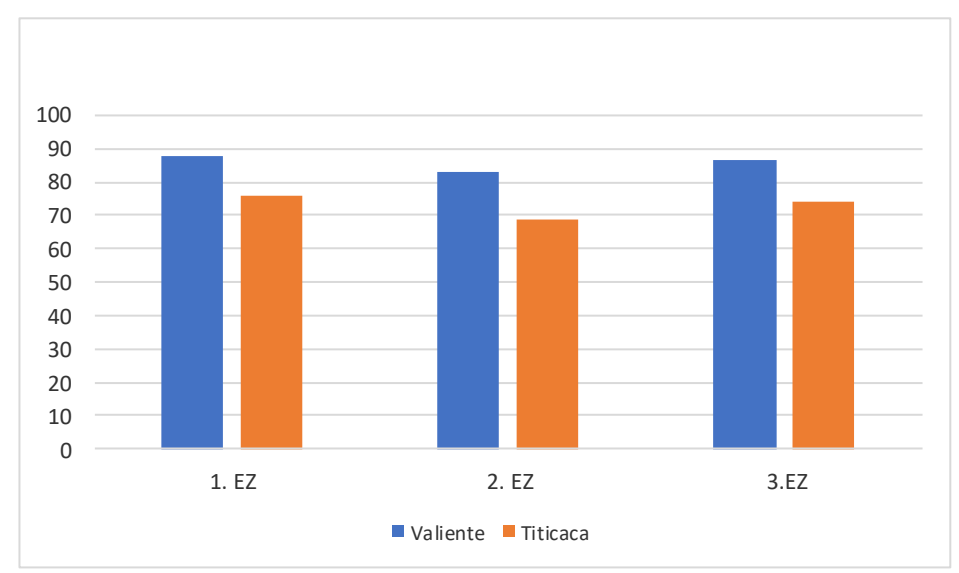

Figure 5. The impact of sowing times on the plant heights in Quinoa. (EZ: sowing time) 


$$
-10111 \text { - }
$$

\section{The main panicle length (cm) and the number of panicle branches (panicle branch ${ }^{-1}$ )}

As is seen in Table 3, according to the results, the variety and variety $\times$ sowing time (ST) interactions were determined to be statistically significant. According to the obtained results, the main panicle length in the Titicaca variety $(38.1 \mathrm{~cm})$ was lower compared to the Valiente variety $(42.8 \mathrm{~cm})$ (Table 5).

Table 5. The impact of different sowing times on the main panicle length and number of panicle branches of quinoa varieties

\begin{tabular}{|c|c|c|c|c|c|c|c|c|}
\hline \multicolumn{5}{|c|}{ Number of plants in the harvest (plants/m²) } & \multicolumn{4}{|c|}{ Plant height $(\mathrm{cm})$} \\
\hline \multicolumn{5}{|c|}{$\begin{array}{l}\text { Sowing times } \\
\end{array}$} & \multicolumn{4}{|c|}{ Sowing times } \\
\hline Variety & 1 & 2 & 3 & Mean & 1 & 2 & 3 & Mean \\
\hline Valiente & $43.1 \mathrm{e}$ & $41.4 \mathrm{e}$ & $43.9 \mathrm{~cd}$ & $42.8 \mathrm{~A}$ & 23.7 & 24.0 & 29.7 & 26.7 \\
\hline Titicaca & $31.1 \mathrm{ef}$ & $43.1 \mathrm{~cd}$ & $41.1 \mathrm{gh}$ & $38.4 \mathrm{~B}$ & 27.7 & 27.6 & 24.7 & 25.7 \\
\hline Mean & 37.1 & 42.2 & 42.5 & & $25.7 \mathrm{~B}$ & $25.8 \mathrm{~B}$ & $27.2 \mathrm{~A}$ & \\
\hline
\end{tabular}

In this research, where the interaction of variety $\times$ sowing time was determined to be significant, the highest main panicle length was $(42.8 \mathrm{~cm})$ determined in the 3 rd sowing time of the Valiente variety, while the lowest main panicle length was $(31.1 \mathrm{~cm})$ determined in the 1st sowing time of the Titicaca variety (Fig. 6).

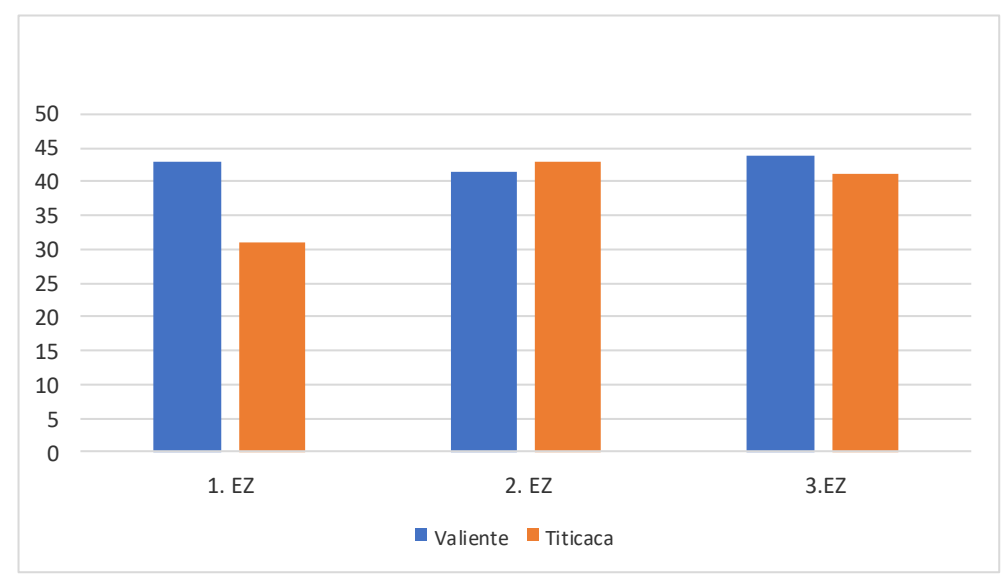

Figure 6. The impact of sowing times on the main panicle length in Quinoa. (EZ: sowing time)

In our study, it was determined that the impact of interactions of variety $\times$ sowing time (ST) on the number of panicle branches was insignificant, while the impact of the sowing time was determined to be statistically significant (Table 3). In this study, the highest number of panicle branches was 27.2 panicle branches $^{-1}$ in the 3 rd sowing time, while the lowest was 25.7 panicle branches ${ }^{-1}$ in the 1 st sowing time (Table 5; Fig. 7).

\section{Thousand weight (g) and grain yield ( $g$ )}

In this study, the impact of sowing times (ST) on the thousand weight of the quinoa varieties was determined to be statistically insignificant (Table 3). According to these results, the thousand weights varied between 3.37-3.46 g (Table 6; Fig. 8). 


$$
-10112 \text { - }
$$

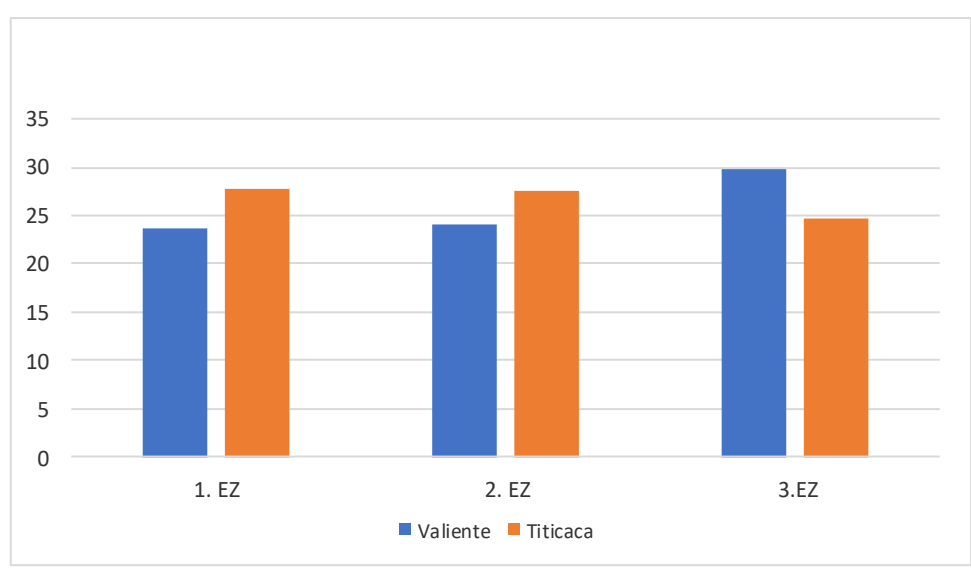

Figure 7. The impact of sowing times on the number of panicle branches in Quinoa. (EZ: sowing time)

Table 6. The impact of different sowing times on the thousand weight and grain yield of quinoa varieties

\begin{tabular}{|c|c|c|c|c|c|c|c|c|}
\hline \multicolumn{5}{|c|}{ Number of plants in the harvest (plants/m²) } & \multicolumn{4}{|c|}{ Plant height $(\mathbf{c m})$} \\
\hline \multicolumn{5}{|c|}{ Sowing times } & \multicolumn{4}{|c|}{ Sowing times } \\
\hline Variety & 1 & 2 & 3 & Mean & 1 & 2 & 3 & Mean \\
\hline Valiente & $43.1 \mathrm{c}$ & $41.4 \mathrm{e}$ & $43.9 \mathrm{~cd}$ & $42.8 \mathrm{~A}$ & 23.7 & 24.0 & 29.7 & 26.7 \\
\hline Titicaca & $31.1 \mathrm{ef}$ & $43.1 \mathrm{~cd}$ & $41.1 \mathrm{gh}$ & $38.4 \mathrm{~B}$ & 27.7 & 27.6 & 24.7 & 25.7 \\
\hline Mean & 37.1 & 42.2 & & & $25.7 \mathrm{~B}$ & $25.8 \mathrm{~B}$ & $27.2 \mathrm{~A}$ & \\
\hline
\end{tabular}

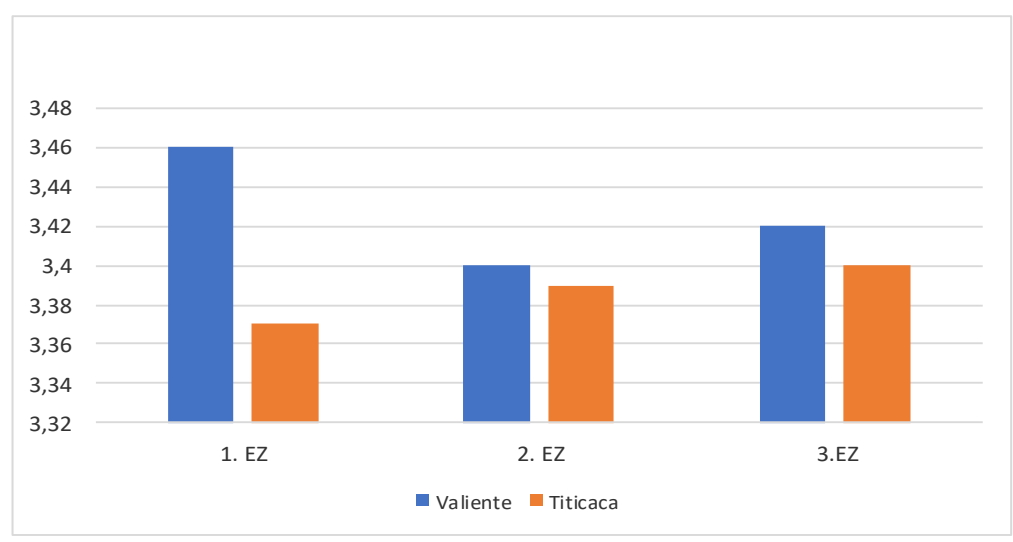

Figure 8. The impact of sowing times on the thousand weight in Quinoa. (EZ: sowing time)

As is seen in the Table 3,131.9 g grain yield was obtained from the Valiente variety, which was found to be statistically significant for the variety and variety $\times$ sowing time interaction, and $128.7 \mathrm{~g}$ grain yield from the Titicaca variety (Tables 3 and 6). The highest grain yield was $134.5 \mathrm{~g}$ in the 3 rd sowing time of the Valiente variety, while the lowest grain yield was determined as $125.6 \mathrm{~g}$ in the 1 st sowing time of the Titicaca variety (Fig. 9). 


$$
-10113 \text { - }
$$

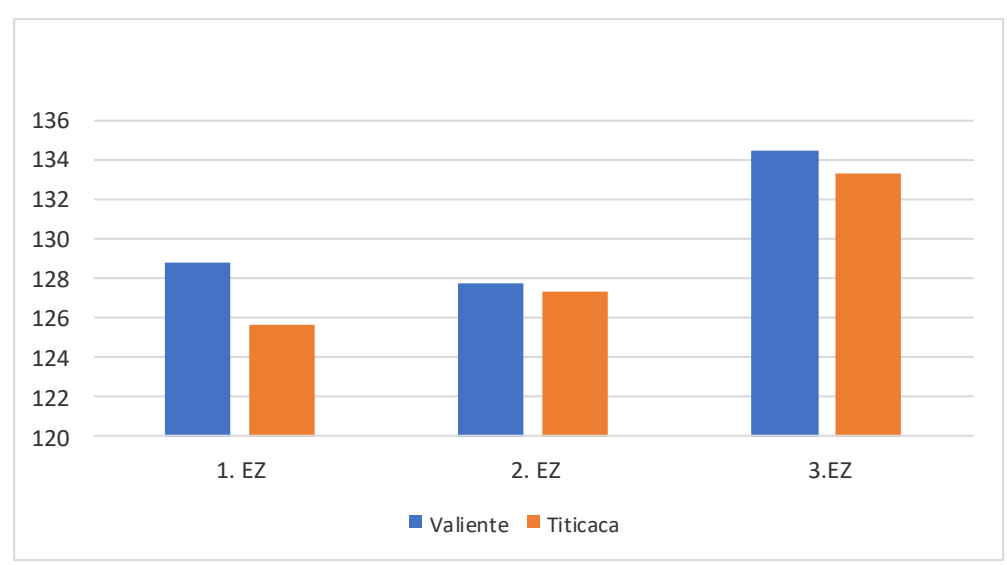

Figure 9. The impact of sowing times on the grain yield in Quinoa. (EZ: sowing time)

\section{Hectoliter weight (kg) and crude protein ratio (\%)}

As is seen in the Table 3, while there was statistically no significant impact of the variety and sowing times (ST) on the hectoliter weight, the variety and sowing times interaction was determined to be statistically significant. According to the results of the study, the highest hectoliter weight was $62.8 \mathrm{~kg}$ in the $3 \mathrm{rd}$ sowing time of the Valiente variety, while the lowest was $62.2 \mathrm{~kg}$ in the 1 st and $3 \mathrm{rd}$ sowing times of the Titicaca variety (Table 7; Fig. 10).

Table 7. The impact of different sowing times on the hectoliter weight and crude protein ratio of quinoa varieties

\begin{tabular}{c|c|c|c|c|c|c|c|c}
\hline \multicolumn{4}{c|}{ Hectoliter weight $(\mathbf{k g})$} & \multicolumn{4}{c}{ Crude protein $(\mathbf{c m})$} \\
\hline \multicolumn{5}{c}{ Sowing times } & \multicolumn{4}{c}{ Sowing times } \\
\hline Variety & $\mathbf{1}$ & $\mathbf{2}$ & $\mathbf{3}$ & Mean & $\mathbf{1}$ & $\mathbf{2}$ & $\mathbf{3}$ & Mean \\
\hline Valiente & $62.4 \mathrm{~b}$ & $62.2 \mathrm{bc}$ & $62.8 \mathrm{a}$ & 62.5 & 15.7 & 15.2 & 15.1 & 15.3 \\
Titicaca & $62.2 \mathrm{bc}$ & $62.6 \mathrm{ab}$ & $62.2 \mathrm{ab}$ & 62.3 & 15.5 & 14.8 & 15.0 & 15.1 \\
Mean & 62.3 & 62.4 & 62.5 & & 15.6 & 15.0 & 15.0 & \\
\hline
\end{tabular}

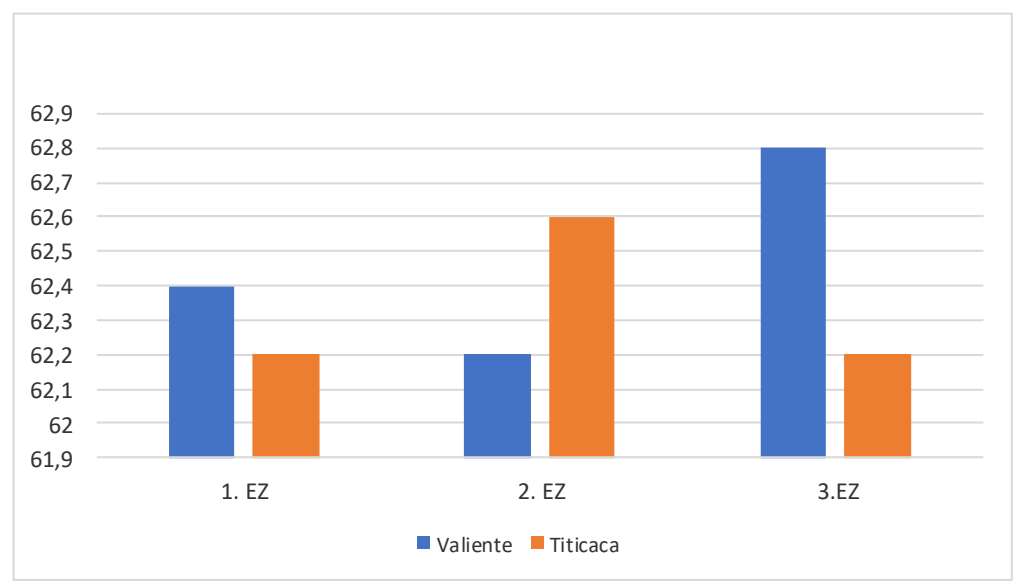

Figure 10. The impact of sowing times on the hectoliter weight in Quinoa. (EZ: sowing time) 
It was determined that there was statistically no significant impact of the variety and sowing times (EZ) on the crude protein ratios (Table 3). However, the mean crude protein ratios obtained in different sowing times from the Valiente and Titicaca varieties were respectively, $15.3 \%$ and $15.1 \%$ (Table 7; Fig. 11).

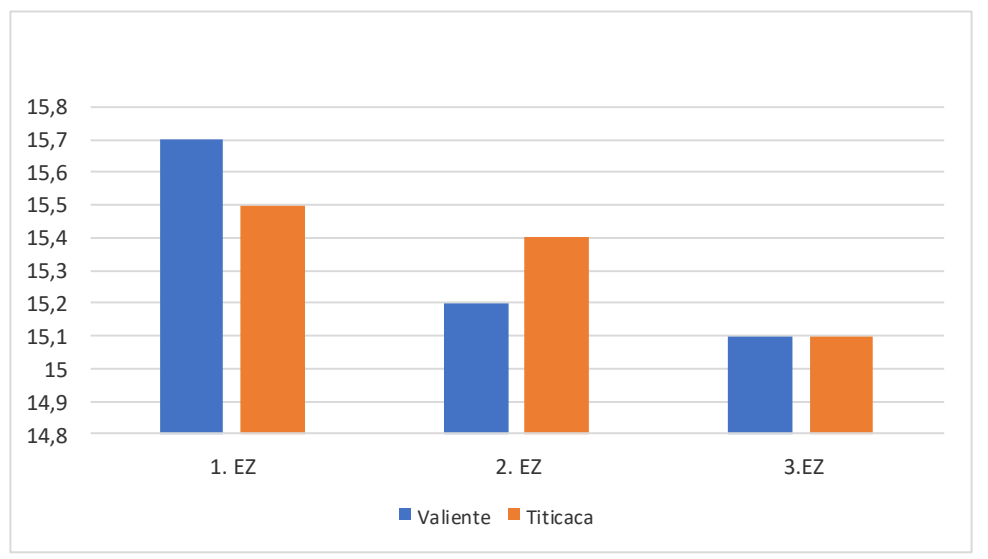

Figure 11. The impact of sowing times on the crude protein ratios in Quinoa. (EZ: sowing time)

\section{Discussion}

In similar studies, it was reported that the number of plants in the harvest is directly relevant to the grain yield (Bertero et al., 2004). The main reason of the lower NPH figure in the 1st sowing time was estimated to be emerging from that the precipitation and temperature levels of the March were lower compared to those of the April. Lower temperature and precipitation negatively influence the first emergence and development of quinoa, causing a decrease in the number of plants in the harvest (Geren et al., 2014).

In a study conducted by Geren et al. (2014), it was reported that the plant height varied between $63.8 \mathrm{~cm}$ and $111.7 \mathrm{~cm}$. According to these results, it is estimated that the plant heights are influenced, to a large extent, from the agricultural implementations applied to the genotypes under different ecological conditions. In a study conducted on different ecology and genotypes, Pulvento et al. (2010) concluded that there were differences in the plant heights of the genotypes. According to the results of the study, the main reason behind the high results of the 3rd sowing time is the increasing temperature and the precipitation in our region. Therefore, we are of the opinion that the first week of the April month might be an appropriate time for a successful quinoa cultivation in our province. In similar studies, it was reported that main panicle length and number of panicle branches had a high and positive impact on the grain yield (Bertero et al., 2004; Bhargava et al., 2007). In a study conducted by Hirich et al. (2014) in the Southern Morocco, different sowing times were implemented ranging between 15 October and 15 March. In that study it was determined that the panicle weight per plant was firstly $24 \mathrm{~g}$, subsequently increasing to $57 \mathrm{~g}$ and ultimately decreasing to $15 \mathrm{~g}$.

Besides the fact that thousand weight is a genotypic characteristic, it is known that it is influenced from the environmental conditions. In a study conducted by Koziol (1993), it was reported that the thousand weight varied between $1.9-4.3 \mathrm{~g}$ based on the variety. In another study conducted by Kaya (2010) under Çukurove conditions, the thousand weight was determined between $2.1 \mathrm{~g}$ and $2.6 \mathrm{~g}$ (Fig. 8). It was considered that the most important motive behind the impact of the sowing times on the grain 
yields of the varieties in the quinoa was that impact of changes in the temperature and precipitation on emergence and germination. This impact influences other herbal characteristics, particularly the number of plants in the unit area, and causes fluctuations in the grain yield (Geren et al., 2014). In similar studies, it was reported that not only the sowings in March, but also sowings in May negatively influence the blossoming and pollination, thus decrease the grain yield (Gonzales et al., 2012). Therefore, in order to determine the accurate sowing time, it was determined that over precipitation and humidity had negative impacts on pollen activity in addition to the negative impacts of dry and hot weather (Aguilar and Jacobsen, 2003). Hectoliter weight is an important criterion in particularly milling, and especially in grains. Moreover, it was reported that ecological factors and cultural implementations can significantly influence the storage and putting on market the seeds (Chauhan et al., 1992; Lindeboom, 2005; Peralta et al., 2006).

The protein ratio of the quinoa was reported to be higher compared to other grains, ranging between $8-22 \%$ (Jancurova et al., 2009). The growing season length has been affected by accumulated radiation. In addition to abiotic factors (temperature, radiation, rainfall) affecting quinoa growth, biotic factors such as downy mildew and weeds affected the yield (Hirich et al., 2014).

\section{Conclusion}

According to the results of this research study, it was considered that the most appropriate sowing time for the quinoa in Mardin province was the second week of April. The best values concerning the most important characters for the cultivation, the grain yield $(133.9 \mathrm{~g})$ and thousand weight $(3.41 \mathrm{~g})$ were obtained from the April 15 sowing time. In our region, where the first product wheat and second product corn agriculture is densely implemented, an alternative income can be created by cropping system among various products. Quinoa is quite appropriate for the mechanized agriculture, the sowing can be employed by the sowing machine, and the harvest can be conducted through harvester. The plant is resistant to drought, needing $250-380 \mathrm{~mm}$ water in the growing period. Particularly in our province, where the irrigation water is insufficient, if there is precipitation after the sowing in the first and second weeks of April, no need arises for irrigation until the mid-June. After this period, it is necessary to employ irrigation. Therefore, considering the high costs of the water obtained from wells based on intense drilling activities, it is necessary to encourage the cultivation of products with high added values and with an economical water use. Further studies can be conducted in this region as well, supporting this product to become widespread. After this study, similar multi-year researches will be conducted on quinoa. Fertilizer, frequency, irrigation time and other quality analyzes are planned for sowing.

\section{REFERENCES}

[1] Aguilar, P. C., Jacobsen, S. E. (2003): Cultivation of quinoa on the Peruvian Altiplano. Food Reviews International 19: 31-41.

[2] Anonymous (2017): Mardin meteroloji bölge istasyonu verileri. https://www.mgm.gov.tr/kurumsal/istasyonlarimiz.aspx (accessed: 20 Sept 2018). 
[3] Battais, F., Courcoux, P., Popineau, Y., Kanny, G., Moneret-Vautrin, D. A., DeneryPaini, S. (2005): Food allergy to wheat: differences in immunoglobulin E-binding proteins as a function of age or symptoms. - Journal of Cereal Science 42: 109-117.

[4] Bertero H. D., de la Vega, A. J., Correa, G., Jacobsen, S. E., Mujica, A. (2004): Genotype and genotype-by-environment interaction effects for grain yield and grain size of quinoa (Chenopodium quinoa Willd.) as revealed by pattern analysis of international multienvironment trials. - Field Crops Research 89: 299-318.

[5] Bhargava, A., Shukla, S., Ohri, D. (2007): Genetic variability and interrelationship among various morphological and quality traits in quinoa (Chenopodium quinoa Willd.). - Field Crops Resarch 101(1): 104-116.

[6] Chauhan, G. S., Eskin, N. A. M., Tkachuk, R. (1992): Nutrients and antinutrients in quinoa seed. - Cereal Chemistry 69: 85-88.

[7] FAO (2017): Plataforma de información de la quinua. - http://www.fao.org/inaction/quinoa-platform/en/ (accessed: 10 Nov 2018).

[8] Geren, H., Kavut, Y. T., Topçu, G. D., Ekren, S., İştipliler, D. (2014): Akdeniz iklimi koşullarında yetiştirilen kinoa (Chenopodium quinoa Willd.)' da farklı ekim zamanlarının tane verimi ve bazı verim unsurlarına etkileri. - Ege Üniversitesi Ziraat Fakültesi Dergisi 51: 297-305.

[9] Gonzalez, J. A., Konishi, Y., Bruno, M., Valoya, M., Pradoc, F. E. (2012): Interrelationships among seed yield, total protein and amino acid composition of ten quinoa (Chenopodium quinoa Wild) cultivars from two different agroecological regions. - Journal Science Food Agriculture 92: 1222-1229.

[10] Hirich, A., Choukr-Allah, R., Jacobsen, S. E. (2014): Quinoa in Morocco - effect of sowing dates on development and yield. - Journal of Agronomy and Crop Science 1: 371-377.

[11] Jancurová, M., Minarovicová, L., Dandar, A. (2009): Quinoa - a review. - Czech Journal of Food Sciences 27: 71-79.

[12] Kaya, Ç. İ. (2010): Akdeniz bölgesinde damla sistemiyle tatlı ve tuzlu su kullanılarak uygulanan farklı sulama stratejilerinin kinoa bitkisinin verimiyle toprakta tuz birikimine etkileri ve saltmed modelinin test edilmesi. - Yüksek Lisans Tezi, Çukurova Üniversitesi Fen Bilimleri Enstitüsü, Adana.

[13] Kaya, E., Karaer, M. (2017): Kinoa yetiştiriciliği ve sağlık açısından önemi. - Türk Bilimsel Derlemeler Dergisi 10: 21-26.

[14] Kır, A. E., Temel, S. (2016): Iğdır ekolojik koşullarında farklı kinoa çeşit ve populasyonlarının tohum verimi ve bazı özelliklerinin belirlenmesi. - Yüksek Lisans Tezi, Iğdır Üniversitesi Fen Bilimleri Fakültesi Tarla Bitkileri Anabilim Dalı, Iğdır.

[15] Kır, A. E., Temel, S. (2017): Sulu Koşullarda Farklı Kinoa (Chenopodium quinoa Willd.) Genotiplerinin Tohum Verimi ile Bazı Tarımsal Özelliklerinin Belirlenmesi. - Iğdır Üni. Fen Bilimleri Enst. Der./Iğdır Univ. J. Inst. Sci. \& Tech. 7(1): 353-361.

[16] Koziol, M. J. (1993): Quinoa: A Potential New Oil Crop. - In: Janick, J., Simon, J. E. (eds.) New Crops. Wiley, New York, pp. 328-336.

[17] Lindeboom, N. (2005): Studies on the characterization, biosynthesis and isolation of starch and protein from quinoa (Chenopodium quinoa Willd.). - Ph.D. Thesis, University of Saskatchewan, Department of Applied Microbiology and Food Science, Canada.

[18] Miranda, M., Vega-Galvez, A., Quispe-Fuentes, I., Rodriguez, M. J., Maureira, H., Martinez, E. A. (2012): Nutritional aspects of six quinoa (Chenepodium quinoa willd.) ecotypes from three geographical areas of Chile. - Chilean Journal of Agricultural Research 72: 175-181.

[19] Özkaya, B. (1999): Tahılların Neden Olduğu Alerjiler ve Önemi 2. - Food Hi-Tech 1: 8288.

[20] Pearsall, D. M. (1992): The Origins of Plant Cultivation in South America. - In: Cowan, C. W., Watson, P. J. (eds.) The Origins of Agriculture. Smithsonian Institute Press Washington, DC, pp.173-205. 
[21] Peralta, E., Mazón, N., Villacrés, E., Taipe, J., Olmos, W. (2006): Sustainable production systems for quaranteeing food security in poor communities of the province of Cotopaxi, Ecuador. - National Autonomous Institute for Agricultural Livestock Breeding Research, Year: 1 Progress Report.

[22] Pulvento, C., Riccardi, M., Lavini, A., d'Andria, R., Iafelice, G., Marconi, E. (2010): Field trial evaluation of two chenopodium quinoa genotypes grown under rain-fed conditions in a typical Mediterranean environment in South Italy. - Journal of Agronomy and Crop Science 196(6): 407-411. 